\title{
RESISTANCE TO GAS FLOW IN THE "NEW" ANAESTHESIA CIRCUITS: A COMPARATIVE STUDY
}

\author{
JOHN SHANDRO
}

\begin{abstract}
The resistance to gas flow is measured in the Jackson-Rees modification of the Ayre's T-piece, the "Bain" circuit, and the circle circuit using the conventionally employed rubber tubing, or either of two coaxial circle tubing systems. The Ayre's T-piece has the lowest resistance to gas flow, followed by the circle circuit with conventional rubber tubing, then the "Bain" circuit and the coaxial circle circuits. When the resistance to gas flow in the inspiratory limb is measured with a tracheal tube attached to each circuit the resistances increase in magnitude, but the differences among the circuits become less significant.
\end{abstract}

KEY WORDS: EQUIPMENT, anaesthetic circuits, resistance.

IN RECENT YEARS new anaesthetic circuits have been developed in response to the need for lightness, compactness, and flexibility. However, in making these circuits smaller, there is the possibility that resistance to gas flow may increase to a clinically unacceptable level. The resistance to inspiration and expiration is of interest because, as resistance increases, so does the work of spontaneous breathing.

Laboratory experiments were set up to measure the resistance to gas flow in several commonly used circuits, comparing the new designs to circuit: customarily used. The circuits tested were the Jackson-Rees modification of the Ayre's T-piece; the "Bain" circuit;" the circle absorber* with the conventional rubber tubing on both limbs, or with the Dalhousie multipurpose circuit ${ }^{2}$ which is similar in dimensions to the MERA F circuit, ${ }^{3}$ or with a coaxial circle developed at the University Hospital in Edmonton. Specifications of these circuits are given in Table I.

There were two parts to the study. In part one resistance to gas flow was compared in the inspiratory and expiratory limbs of the circuits. In part two a tracheal tube was added to each circuit to determine the total resistance in the inspiratory limb of clinically used circuit-tube combinations.

*British Oxygen Co. Mk 4 circle absorber. John Shandro, M.D., Resident in Anaesthesia, University Hospital, Edmonton, Alberta.

\section{Materials and Methods}

\section{Part One}

All circuits were fully assembled and in the circle the carbon dioxide absorber was included. Pressure relief valves were closed and compressed air was fed into the fresh gas inlet of each circuit at six litres per minute in the Ayre's T-piece and "Bain" circuits, and at two litres per minute into the circle circuits. A variable flow generator* was employed to blow air at room temperature through each circuit through either the inspiratory limb or the expiratory limb. The ports of entry and exit employed in each circuit are shown in Figure 1. There were five trials for each circuit. Between the trials each circuit was disassembled and reassembled. The system was allowed to stabilize at each flow rate for fifteen seconds before the pressure was recorded. The amount of pressure required to achieve a flow rate of 30 litres per minute was measured at the point at which air entered the circuit by means of a diaphragm type strain gauge $\dagger$ calibrated to a water manometer standard.

\section{Part Two}

Tracheal tubes were connected to the patient end of the circuits and the measurements of pressure required to achieve a given flow rate through the inspiratory limb of each circuit were

*Godart Flow Generator, N. V. Godart Co., Holland.

† Statham differential pressure transducer, Statham Laboratories Inc., Hato Rey, Puerto Rico. 
TABLE I

Specifications of ANaesthetic Circuits Studied

\begin{tabular}{|c|c|c|c|c|c|c|c|}
\hline \multirow[b]{2}{*}{ Circuit } & \multirow[b]{2}{*}{$\begin{array}{c}\text { External } \\
\text { size }(\mathrm{mm})\end{array}$} & \multicolumn{2}{|c|}{$\underset{(\mathrm{mm})}{\text { Minimum internal diameter }}$} & \multicolumn{2}{|c|}{$\begin{array}{l}\text { Minimum cross section } \\
\text { area of lumen }\left(\mathrm{cm}^{2}\right)\end{array}$} & \multirow[b]{2}{*}{$\begin{array}{l}\text { Length } \\
\text { (cm) }\end{array}$} & \multirow[b]{2}{*}{ Manufacturer } \\
\hline & & $\begin{array}{l}\text { Inspiratory } \\
\text { limb }\end{array}$ & $\begin{array}{l}\text { Expiratory } \\
\text { limb }\end{array}$ & $\begin{array}{l}\text { Inspiratory } \\
\text { limb }\end{array}$ & $\begin{array}{l}\text { Expiratory } \\
\text { limb }\end{array}$ & & \\
\hline $\begin{array}{l}\text { Ayre's T-piece } \\
\text { (Jackson-Rees } \\
\text { modification } \\
\text { without bag) }\end{array}$ & 24 & 15 & 15 & 1.77 & 1.77 & 32 & $\begin{array}{l}\text { British } \\
\text { Oxygen }\end{array}$ \\
\hline Bain & 28 & $\begin{array}{l}22 \text { (minus } 12 \\
\text { fresh gas } \\
\text { supply tube) }\end{array}$ & $\begin{array}{l}22 \text { (minus } 12 \\
\text { fresh gas } \\
\text { supply tube) }\end{array}$ & 2.66 & 2.66 & 192 & Penlon \\
\hline $\begin{array}{l}\text { Conventional } \\
\text { circle (two tubes) }\end{array}$ & 34 & 22 & 22 & 3.79 & 3.79 & 90 & $\begin{array}{l}\text { British } \\
\text { Oxygen }\end{array}$ \\
\hline $\begin{array}{l}\text { Dalhousie } \\
\text { multi-purpose }\end{array}$ & 28 & 10 & $\begin{array}{l}22 \text { (minus } 12 \\
\text { inspiratory } \\
\text { limb) }\end{array}$ & 0.78 & 2.66 & 100 & M.I.E. \\
\hline $\begin{array}{l}\text { Coaxial } \\
\text { circle } \\
\text { (Edmonton) }\end{array}$ & 38 & $\begin{array}{l}30 \text { (minus } 18 \\
\text { expiratory } \\
\text { limb) }\end{array}$ & 15 & 1.77 & 3.92 & 160 & $\begin{array}{l}\text { prototype } \\
\text { University } \\
\text { Hospital, } \\
\text { Edmonton. }\end{array}$ \\
\hline
\end{tabular}

repeated. To determine the resistance to gas flow for anaesthesia for adults, flow rates of 30 litres per minute were used with $8.0,7.5$, and $7.0 \mathrm{~mm}$ internal diameter tracheal tubes in the "Bain" and circle circuits. For paediatrics, the T-piece and "Bain" circuits were compared. Flow rates of 20 litres per minute were used with 6.0 and $5.0 \mathrm{~mm}$ internal diameter tracheal tubes, and flow rates of 10 litres per minute were used with 4.0 and $3.0 \mathrm{~mm}$ internal diameter tracheal tubes.

\section{RESULTS}

The data were subjected to analysis of vari-

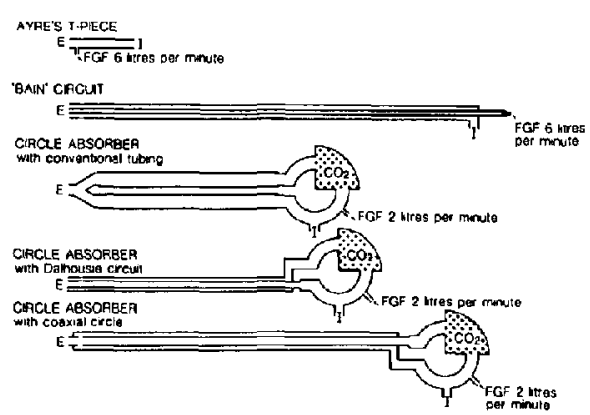

FIGURE 1 "I" is the point at which gas entered the circuit for measurements of inspiratory resistance. " $E$ " is the point at which gas entered the circuit for measurements of expiratory resistance. ance. The results are displayed graphically in Figures 2, 3, and 4 .

\section{Part One}

With no tracheal tube on the circuits (Figure 2), the Ayre's T-piece had the lowest resistance to gas flow, followed by the conventional rubber tubing circle, then the coaxial circle (Edmonton), and then the "Bain" and Dalhousie circuits. The expiratory resistance of the "Bain", coaxial circle (Edmonton), and Dalhousie circuits were not significantly different, all other resistance

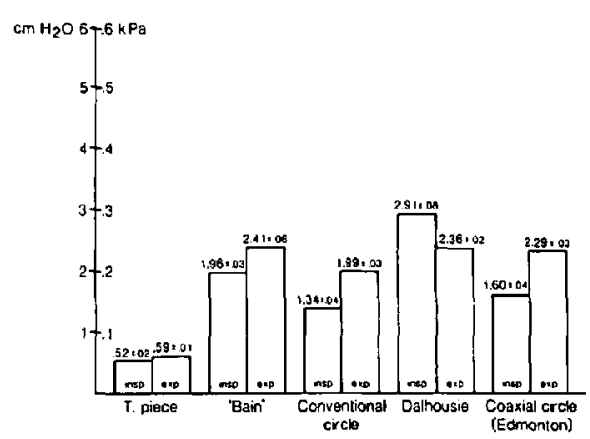

FIGURE 2 Pressure required to overcome resistance to gas flow of 30 litres per minute through the circuits, plus or minus one standard deviation. "Insp" denotes inspiratory limb; "exp" denotes expiratory limb. 


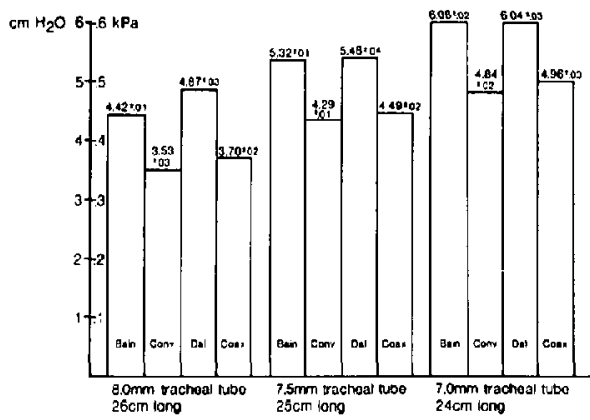

FiguRE 3 Pressure required to overcome resistance to gas flow of 30 litres per minute through the inspiratory limb of the circuits with tracheal tubes attached, plus or minus one standard deviation. "Bain" denotes Bain circuit, "Conv" denotes $22 \mathrm{~mm}$ intemal diameter rubber circle tubing, "Dal" denotes Dalhousie circuit, "Coax" denotes coaxial circle circuit (Edmonton).

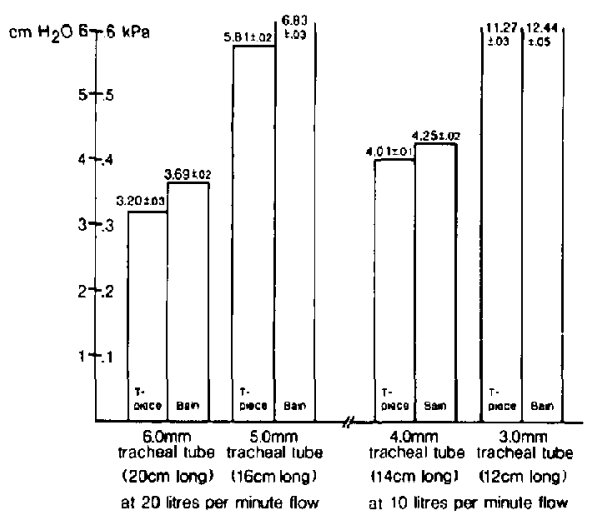

FIGURe 4 Pressure required to overcome resistance to gas flows of 20 litres per minute and 10 litres per minute respectively, plus or minus one standard devia.ion; through the inspiratory limb of the circuits with tracheal tubes attached.

measurements in Part One were significantly different $(\mathrm{p}<0.5)$.

\section{Part Two}

When tracheal tubes were added to the circuits usually employed in adults (Figure 3), the conventional rubber circle had the lowest resistance to gas flow in the inspiratory limb, followed closely by the coaxial circle (Edmonton) then the "Bain" and Dalhousie circuits. The resistance to gas flow in the inspiratory limb of the "Bain" and Dalhousie circuits with a $7.0 \mathrm{~mm}$ internal diameter tracheal tube attached were not significantly different, nor were resistances to gas flow in the inspiratory limbs of the coaxial circle (Edmonton) and conventional circle circuits with a 7.0 mm internal diameter tracheal tube attached. All other resistance measurements in part two were significantly different $(\mathrm{p}<0.5)$. When the Ayre's T-piece and "Bain" circuits were compared with tracheal tubes of sizes commonly employed in children (Figure 4), the "Bain" circuit had a consistently higher resistance to gas flow through the inspiratory limb than the T-piece. It should be noted that, without tracheal tubes, the T-piece has approximately 25 per cent of the flow resistance of the "Bain" circuit, and this is presumably due to the presence of the fresh gas supply line in the lumen of the "Bain" circuit. However, with tracheal tubes attached the resistances in the inspiratory limbs of the circuits differ by only 5 to 15 per cent.

\section{Discussion}

Resistance to gas fow in anaesthetic circuits and components has been studied extensive$1 y^{4,5}$ and guidelines for the maximum permissible resistance for spontaneous breathing in adults have been established by Nunn. ${ }^{6}$ These standards will likely be adopted by the Canadian Standards Association.?

All circuits studied had resistance to gas flow below Nunn's suggested maximum of $0.3 \mathrm{kPa}$ (3 $\mathrm{cm} \mathrm{H}_{2} \mathrm{O}$ ) at 30 litres per minute when no tracheal tube was connected. All circuits had resistances over Nunn's suggested maximum when tracheal tubes were connected. The resistances among all circuits differed by $0.14 \mathrm{kPa}\left(1.4 \mathrm{~cm} \mathrm{H}_{2} \mathrm{O}\right)$ at most with tracheal tubes connected.

The peak inspiratory flow rate generated by normal tidal volumes in adults is in the range of 20 to 28 litres per minute. ${ }^{8.9}$ Therefore, I consider it reasonable to believe that the resistance to gas flow at 30 litres per minute measured in the laboratory in the inspiratory limbs of circuits with tracheal trubes attached is equivalent to the resistance to inspiration experienced by patients breathing spontaneously on those same circuits.

Admittedly the gas used to determine resistance in these experiments was air, not a nitrous oxide/oxygen mixture. Since gas flow in anaesthesia circuits is largely turbulent, the gas density is important in influencing resistance. The density of nitrous oxide/oxygen mixture 70 per cent: 30 per cent is greater than that of air and in this case the resistances would be about 25 per 
cent greater than the values derived from these experiments.

Moisture content of the gas is also important. High moisture content would tend to decrease the resistance to gas flow, water vapour being less dense than air. Because moisture content is much higher during spontaneous breathing with the circle circuits than during spontaneous breathing with the T-piece or "Bain" circuits, ${ }^{10}$ the resistance to gas flow would tend to be slightly lower than the values derived for the circle circuits in this study.

With artificial ventilation, only the expiratory resistance is of consequence, since most ventilators can overcome moderate inspiratory resistance. Any expiratory resistance will manifest itself as positive end expiratory pressure (PEEP). During spontaneous breathing, however, an increase in inspiratory resistance will increase the work of breathing ${ }^{11}$ and the degree of inspiratory resistance which can be tolerated depends on the patient's clinical condition.

\section{CONCLUSions}

The size of the tracheal tube is the major factor governing resistance in anaesthetic breathing systems. All anaesthetic circuits in common use have resistance to gas flow below $0.3 \mathrm{kPa}(3 \mathrm{~cm}$ $\mathrm{H}_{2} \mathrm{O}$ ) at 30 litres per minute without tracheal tubes and all have resistance to gas flow above $0.3 \mathrm{kPa}\left(3 \mathrm{~cm} \mathrm{H}_{2} \mathrm{O}\right)$ in the inspiratory limbs at 30 litres per minute with tracheal tubes connected. The circuit with the least resistance to spontaneous breathing for adults is the circle absorber with the standard $22 \mathrm{~mm}$ internal diameter tubing. The circuit with the least resistance to spontaneous breathing for children is the Ayre's T-piece. As the differences among all the circuits are small the anaesthetist may feel free to concentrate on other aspects of use such as the likelihood of malfunction, sterilisability, and cost.

\section{REFERENCES}

I. BAIN, J.A. \& SPOEREL, W.E. A streamlined anaesthetic system. Can. Anaesth. Soc. J. 19: 426 (1972)

2. JOULES, C.P. Personal communication.

3. Byrick, R.J., JansSen, E. \& Yamashita, M. Rebreathing and Co-Axial Circuits: Comparison of Bain and MERA F. Can. Anaesth. Soc. J. 28: $321(1981)$

4. NUNN, J.F. \& EzI-Ashi, T.I. The respiratory effects of resistance to breathing in anaesthetized man. Anaesthesiology 22: 174 (1961)

5. Proctor, D.F. Studies of respiratory air flow IV. Reistance to air flow through anaesthesia appara. tus. Bull. Johns Hopkins Hosp. 96: 49 (1955).

6. NunN, J.F. Applied Respiratory Physiology, 2nd Edition, Butterworth and Co. page 109 (1977).

7. Z168.9 Breathing Systems for use in Anaesthesia and Respiratory Therapy, Canadian Standards Association, Rexdale, Ontario.

8. CAIN, C.C. \& OTIS, A.B. Some physiological effects resulting from added resistance to respiration. J. Aviation Medicine 20:149 (1949).

9. NunN, J.F. \& EzI-Ashl, T.I. The accuracy of the respirometer and ventigrator. Brit. J. Anaes. 34: 422 (1962).

10. SHANDRO. J. Unpublished data

11. Roussos, C., Grassino, A. \& Macklem, P.T Inspiratory muscle fatigue and acute respiratory failure. Can. Med. Assn. Jnl. 122; 1375 (1980).

\section{RÉSUMÉ}

On a mesuré la résistance à l'écoulement gazeux dans le tube en T d'Ayre, le circuit de "Bain", le circuit circulaire avec tube conventionnel en caoutchouc et le même circuit avec des tubulures coaxiales. Le tube d'Ayre est celui qui offre la plus faible résistance à l'écoulement des gaz, suivi par le circuit circulaire avec tubulure conventionnelle en caoutchouc, du circuit de "Bain" et des circuits circulaires utilisant des tubulures coaxiales. Lorsque la résistance à l'écoulement gazeux du côté inspiratoire est mesurée avec un tube trachéal en place l'importance des résistances augmente mais les différences entre les circuits deviennent moins significatives. 